\title{
Prospek Dan Tantangan Hukum Internasional Di ASEAN Dan Indonesia Pasca Piagam ASEAN Dari Sisi Perjanjian Internasional
}

\author{
Eddy Pratomo \\ Direktorat Jenderal Hukum Dan Perjanjian Internasional \\ Gedung Utama Lantai 11, Jl. Taman Penjambon No. 6 Jakarta
}

\begin{abstract}
After the establishment of Asian Charter, the agenda to which Asian countries shall address is that its implementation urgently requires a strong political will and the sufficient supporting framework. For Indonesia, the prospect and challenge for the implementation of this charter is mostly in the form of the reformation of the law pertinent to the law of international organization. From international perspective, the position of Indonesia as the hosts of the Asian headquarter may significantly affect the development of international law, especially on he law of international organization.
\end{abstract}

Keywords: International Law, Asian Charter, Asian Agreement.

\section{Pendahuluan}

Sejak didirikan tahun 1967 yang lalu eksistensi ASEAN sebagai organisasi internasional ditingkat internal (regional) maupun eksternal (internasional) belumlah memuaskan. Personalitas Internasional serta tingkat integritasnya sangat rendah dibandingkan organisasi-organisasi regional yang lain terlebih European Union. ASEAN memiliki The High Council untuk menyelesaikan sengketa internaional antar anggotanya. Namun belum pernah sekalipun lembaga ini digunakan. Dalam menyelesaikan Sengketa Sipadan Ligitan misalnya Indonesia dan Malaysia lebih memilih penyelesaian melalui Mahkamah Internasional daripada The High Council. Masalah pelanggaran HAM di Myanmar juga tidak pernah ditanggapi serius oleh ASEAN. Penerapan prinsip non intervensi yang sangat kaku juga ketiadaan pengadilan HAM regional sebagaimana 
dimiliki organisasi regional lainnya merupakan sebagian faktor penyebabnya. Masalah liberalisasi perdagangan tingkat regionalpun juga banyak memiliki permasalahan. Menghadapi semua permasalahan di atas kesepuluh negara anggota mengupayakan penguatan ASEAN dengan menyusun ASEAN CHARTER. Sebagian pihak menyatakan bahwa ASEAN akan lebih diperhitungkan pasca Piagam. Namun demikian sebagian pihak yang lain menyatakan kepesimisannya bahwa tidak banyak perubahan yang dibawa oleh Piagam. ASEAN akan tetap seperti sebelumnya, tidak memiliki wewenangan untuk menindak negara anggota yang melakukan pelanggaran hukum internasioal. Akhir tahun ini kesepuluh negara anggota telah meratifikasinya sebagai syarat dapat diberlakukannya Piagam tersebut. Bagaimana prospek dan tantangan penerapan hukum dan hubungan internasional bagi Indonesia dan ASEAN pasca pemberlakuan ASEAN sangatlah menarik kiranya untuk dikaji.

\section{Sejarah Piagam Asean}

Piagam ASEAN sebagai perjanjian internasional ${ }^{1}$ lahir dari rangkaian proses panjang negosiasi. Menyelaraskan dan kemudian menyepakati kepentingan - kepentingan dari sepuluh negara ASEAN $^{2}$ dalam satu wadah bersama yang mengikat secara hukum hanyalah satu dari sekian banyak usaha diplomasi yang harus dilakukan demi lahirnya Piagam ASEAN. Perdamaian, stabilitas, kemajuan dan kesejahteraaan bersama kawasan antara lain menjadi kepentingan dasar yang pada akhirnya dapat menyatukan negara-negara Asia Tenggara dalam sebuah wadah ASEAN.

Rangkaian proses panjang negosiasi dapat dilihat, antara lain, dari pembentukan Deklarasi Kuala Lumpur tentang Pembentukan Piagam

${ }^{1}$ Definisi Perjanjian Internasional, Pasal 2 (1) (a) Konvensi Wina tentang Hukum Perjanjian 1969 "treaty" means an international agreement concluded between States in written form and governed by international law, whether embodied in a single instrument or in two or more related instruments and whatever its particular designation; Pasal 1 (a) Undang-Undang No.24 Tahun 2000 tentang Perjanjian Internasional "Perjanjian Internasional adalah perjanjian, dalam bentuk dan nama tertentu, yang diatur dalam hukum internasional yang dibuat secara tertulis serta menimbulkan hak dan kewajiban di bidang hukum publik"; Lihat juga Anthony Aust, Modern Treaty Law and Practice, Cambridge University Press, 2000. hlm. 14

${ }^{2}$ Brunei Darussalam, Filipina, Indonesia, Kamboja, Laos, Malaysia, Singapura, Myanmar, Thailand dan Viet nam 
ASEAN pada tanggal 12 Desember 2005, Eminent Persons Group on the ASEAN Charter atau $\mathrm{EPG}^{3}$ dan High Level Task Force on the Drafting of ASEAN Charter atau HLTF. ${ }^{4}$ Proses panjang negoisasi juga membuahkan Travaux Preparatoirs atau dokumen-dokumen persiapan dari Piagam ASEAN mencakup dan tidak terbatas pada Catatan Kesimpulan atau Summary Records dari EPG, HLTF, Kesepakatan II Bali, Deklarasi Kuala Lumpur tentang Pembentukan Piagam ASEAN dan Deklarasi Cebu tentang Cetak Biru Piagam ASEAN.

Setelah proses negosiasi di tingkat regional dapat dilewati yang menghasilkan penandatangananPiagam ASEAN, proses berikutnya adalah ratifikasi ${ }^{5}$ dari setiap negara anggota ASEAN. Proses internal ratifikasi pun bukanlah hal yang mudah. Tercatat setidaknya ada tiga negara anggota $\mathrm{ASEAN}^{6}$ yang menyerahkan instrumen ratifikasi ${ }^{7}$ pada

${ }^{3}$ Terms of Reference atau TOR EPG disepakati pada Pertemuan Ke-11 Kepala Negara ASEAN atau ASEAN Summit di Kuala Lumpur, Malaysia, Desember 2005; Di dalam TOR, EPG yang terdiri dari "highly distinguished and well respected citizens" dari setiap negara ASEAN mempunyai mandat untuk "...examine and provide practical recommendations on the directions and nature of the ASEAN Charter relevant to the ASEAN Community as envisaged in the Bali Concord II and beyond, taking into account, but not limited to, the principles, values and objectives contained in this Declaration": Lebih jauh EPG diminta untuk "...examine ASEAN in all areas of its cooperation activities, codify and build upon all ASEAN norms, principles, values and goals as contained in ASEAN's milestone agreements, treaties and declarations, as well as undertake a thorough review of the existing ASEAN institutional framework and propose appropriate improvements if so required. It will put forth bold and visionary recommendations on the drafting of an ASEAN Charter, which will serve as the legal and institutional framework for ASEAN, aimed at enabling the building of a strong, prosperous, and caring and sharing ASEAN Community that is cohesive, successful and progressing in the 21st century"

${ }^{4}$ Terms of Reference atau TOR HLTF disepakati pada Pertemuan Ke-11 Kepala Negara ASEAN atau ASEAN Summit di Kuala Lumpur, Malaysia, Desember 2005; Di dalam TOR HLTF yang terdiri dari pejabat senior dari masing-masing negara ASEAN diberikan mandat untuk "...draft the ASEAN Charter based on the directions given by the Leaders as reflected in the Kuala Lumpur Declaration on the Establishment of the ASEAN Charter and the Cebu Declaration on the Blueprint of the ASEAN Charter and in consideration of the recommendations made by the EPG and other relevant ASEAN documents"

${ }^{5}$ Pasal 47 Ayat 2 Piagam ASEAN "This Charter shall be subject to ratification by all ASEAN Member States in accordance with their respective internal procedures"

${ }^{6}$ Tiga Negara ASEAN yang menyerahkan instrumen ratifikasi terakhir adalah Filipina pada tanggal 12 November 2008, Indonesia pada tanggal 13 November 2008 dan Thailand pada tanggal 14 November 2008.

${ }^{7}$ Pasal 47 Ayat 4 Piagam ASEAN "This Charter shall enter into force on the thirtieth day following the date of deposit of the tenth instrument of ratification with the Secretary-General of ASEAN" 
waktu yang relatif dekat dengan batas waktu rencana awal tanggal keberlakuan Piagam ASEAN yaitu pada Pertemuan Ke-14 Kepala Negara ASEAN, 14 Desember 2008 di Thailand. Di Indonesia, proses ratifikasi melalui Komisi I Dewan Perwakilan Rakyat (Komisi I DPR) mempunyai arti tersendiri. Peran pro-aktif dan kritis dari anggota Komisi I DPR dalam membedah Piagam ASEAN sedikit banyak memberikan masukan bagi pihak Pemerintah untuk lebih jauh mempersiapkan tindak lanjut dari Piagam ASEAN. ${ }^{8}$ Akhirnya setelah melalui perdebatan panjang, pada tanggal 6 Nopember 2008 Piagam ASEAN menjadi bagian dari hukum nasional Indonesia melalui Undang-Undang No 38 Tahun 2008 tentang Pengesahan Charter of the Association of Southeast Asian Nations (Piagam Perhimpunan Bangsa-Bangsa Asia Tenggara).

Piagam ASEAN ${ }^{9}$ yang ditandatangani pada tanggal 20 November 2007 dan diratifikasi oleh seluruh negara anggota ASEAN telah secara de jure mengubah ASEAN dari organisasi kawasan yang longgar menjadi sebuah organisasi yang berdasarkan aturan atau rules-based organisation. Keberadaan Piagam ASEAN memberikan kerangka hukum dan institusional bagi ASEAN untuk berkembang ke arah sebuah komunitas bersama yang mengedepankan antara lain perdamaian, keamanan, stabilitas, pertumbuhan ekonomi berlanjut, kesejahteraan dan kemajuan sosial. ${ }^{10}$

\section{Tindak Lanjut Piagam Asean}

Sebagai tindak lanjut penandatanganan Piagam ASEAN, para Menteri Luar Negeri ASEAN telah menyepakati antara lain untuk membentuk sebuah kelompok kerja yang bertugas untuk membahas isuisu hukum yang mungkin muncul dalam pelaksanaan Piagam ASEAN. Kelompok kerja tersebut adalah High Level Legal Experts' Group on the Follow-up to the ASEAN Charter (HLEG) yang beranggotakan para ahli hukum perwakilan dari setiap negara anggota ASEAN. ${ }^{11}$ Beberapa isu

${ }^{8}$ Beberapa isu dari Piagam ASEAN yang disoroti oleh Komisi I DPR adalah antara lain, mekanisme pengambilan keputusan, sanksi, badan hak asasi manusia dan keterlibatan elemen masyarakat yang masih dirasakan kurang diperhatikan

${ }_{9}^{9}$ Piagam ASEAN mulai berlaku atau entry into force pada tanggal 14 Desember 2008

${ }^{10}$ Lihat Bagian Pembukaan Piagam ASEAN

${ }^{11}$ Terms of Reference atau TOR HLEG disepakati pada Pertemuan ASEAN Foreign Ministers' Retreat di Singapura, 20 Februari 2008; Di dalam TOR, HLEG diminta untuk "...address the implementation of legal matters in the ASEAN Charter..." 
hukum utama yang menjadi pembahasan adalah antara lain mengenai personalitas berikut kapasitas hukum ASEAN, mekanisme penyelesaian sengketa ASEAN dan hak-hak kekebalan dan keistimewaan ASEAN.

Tindak lanjut dari Piagam ASEAN, utamanya implementasi dari setiap ketentuan Piagam ASEAN adalah prospek dan tantangan baik bagi ASEAN maupun Indonesia sendiri. Hal ini menjadi lebih menarik mengingat negara-negara anggota ASEAN dapat melakukan review terhadap Piagam ASEAN pada tahun 2013. ${ }^{12}$ Seiring dengan hal tersebut, implementasi Piagam ASEAN juga sudah pasti memberikan warna baru dalam perkembangan hukum internasional baik di ASEAN dan Indonesia.

\section{Piagam Asean Sebagai Sebuah Perjanjian Internasional}

\section{A. Anatomi Piagam Asean}

Piagam ASEAN terdiri dari 14 bagian besar termasuk pembukaan yang memuat dasar-dasar pembentukan Piagam ASEAN. Empat belas bagian besar kemudian diturunkan ke dalam 55 (lima puluh lima) pasal yang mengatur tidak saja organisasi ASEAN melainkan juga aturanaturan umum yang harus digunakan oleh para anggota ASEAN dalam berinteraksi di ASEAN seperti contohnya mekanisme penyelesaian sengketa di ASEAN.

Bagian dari Piagam ASEAN yang menjadi pusat dari seluruh bagian lainnya adalah bagian pertama, yaitu tujuan dan prinsip. Bagian ini memuat 15 tujuan Piagam ASEAN dan 14 prinsip ASEAN yang harus dihormati oleh seluruh negara anggota ASEAN..$^{13}$ Dapat dikatakan juga bahwa bagian tujuan dan prinsip ini adalah prinsip-prinsip dasar ASEAN yang telah terbentuk, berevolusi dan menjadi kebiasaan ASEAN sejak $1967^{14}$ sampai sekarang.

Bagian yang relatif baru dan merupakan refleksi dari perkembangan jaman adalah antara lain Bab VII Pengambilan Keputusan, Bab VIII Penyelesaian Sengketa dan Bab IV Organ khususnya Pasal 14 tentang kewajiban untuk membentuk sebuah badan hak asasi manusia di HAM. Di dalam Bab VII, Pengambilan Keputusan, Piagam ASEAN telah

\footnotetext{
${ }^{12}$ Pasal 50 Piagam ASEAN "This Charter may be reviewed five years after its entry into force or as otherwise determined by the ASEAN Summit"

${ }^{13}$ Lihat Pasal 1 dan 2 Piagam ASEAN

${ }^{14}$ Pembentukan ASEAN melalui Deklarasi Bangkok, 8 Agustus 1967
} 
melangkah lebih maju dari prinsip konsensus yang selama ini dipakai tanpa ada pengecualian. Bab VII, khususnya Pasal 20 ayat 2 memungkinkan mekanisme lain selain konsensus jika prinsip ini tidak dapat dilakukan. ${ }^{15}$ Mekanisme ini diserahkan kepada ASEAN Summit yang tidak saja dapat memutuskan sebuah permasalahan tetapi juga cara untuk menyelesaikannya. Frase "how a specific decision can be made" memberikan ruang untuk hal ini.

Bab VIII tentang mekanisme penyelesaian sengketa merupakan salah satu dari penyempurnaan penyelesaian sengketa di ASEAN. Selain memberikan pengakuan terhadap mekanisme yang telah ada dan berlaku atau existing mechanisms, ${ }^{16}$ BAB VIII juga memandatkan agar ASEAN membentuk "appropriate dispute settlement mechanism[s]". ${ }^{17}$ Yang menarik dari keberadaan Bab VIII ini, khususnya Pasal 25 adalah hampir seluruh jenis mekanisme penyelesaian sengketa yang dikenal di dunia internasional ${ }^{18}$ dicantumkan secara eksplisit kecuali mekanisme pengadilan. Bukan suatu yang mustahil, jika di masa mendatang kita akan menjadi saksi lahirnya sebuah badan pengadilan ASEAN melalui ketentuan dari Pasal 25 tersebut di atas.

Bab IV, utamanya Pasal 14 Piagam ASEAN secara jelas mewajibkan ASEAN untuk membentuk sebuah badan HAM ASEAN. Ketentuan dari badan HAM ASEAN saat ini masih dinegosiasikan oleh High Level Panel

\footnotetext{
${ }^{15}$ Pasal 20 Ayat 2 Piagam ASEAN, "Where consensus cannot be achieved, the ASEAN Summit may decide how a specific decision can be made"

${ }^{16}$ Lihat Pasal 24 Piagam ASEAN “(1). Disputes relating to specific ASEAN instruments shall be settled through the mechanisms and procedures provided for in such instruments (2). Disputes which do not concern the interpretation or application of any ASEAN instrument shall be resolved peacefully in accordance with the Treaty of Amity and Cooperation in Southeast Asia and its rules of procedure; (3). Where not otherwise specifically provided, disputes which concern the interpretation or application of ASEAN economic agreements shall be settled in accordance with the ASEAN Protocol on Enhanced Dispute Settlement Mechanism"

${ }^{17}$ Penebalan dan garis bawah ditambahkan oleh Penulis untuk menunjukan kuantitas mekanisme yang lebih dari satu; Lihat Pasal 25 Piagam ASEAN “Where not otherwise specifically provided, appropriate dispute settlement mechanisms, including arbitration, shall be established for disputes which concern the interpretation or application of this Charter and other ASEAN instruments"

${ }^{18}$ Pasal 22 Piagam ASEAN menyebutkan Dialog, Konsultasi dan Negosiasi, Pasal 23 Piagam ASEAN menyebutkan Jasa Baik, Mediasi dan Konsiliasi, Pasal 25 Piagam ASEAN menyebutkan Arbitrase, Pasal 33 Piagam ASEAN menyebutkan penyelesaian eksternal Perserikatan Bangsa-Bangsa dan instrumen lainnya.
} 
on an ASEAN human rights body atau HLP yang terdiri dari pejabat senior perwakilan setiap negara anggota ASEAN. ${ }^{19}$

\section{B. Hak Dan Kewajiban Negara Pihak Piagam Asean}

Secara umum, hak dan kewajiban negara ASEAN tidak diatur secara khusus mengingat karakter piagam dari Piagam ASEAN yang bersifat umum. Piagam hanya menyatakan bahwa setiap negara anggota mempunyai bagian yang sama berkenaan dengan hak dan kewajiban di ASEAN. ${ }^{20}$ Sebagai contoh, dalam hal kewajiban kontribusi tahunan kepada ASEAN, setiap negara anggota mempunyai jumlah yang sama yaitu sekitar USD 900.000 per tahunnya. Dalam hal hak, sebagai contoh, negara anggota ASEAN mempunyai satu hak suara dalam hal pengambilan keputusan.

\section{Perbandingan Piagam Asean Dengan Piagam Pembentukan Organisasi Kawasan Lainnya}

Jika membandingkan Piagam ASEAN dengan piagam pembentukan organisasi kawasan lainnya yang mempunyai karakter non-supra nasional yaitu, Organisation of African Union 1963 (OAU), Organisation of American States 1948 (OAS) dan Organisation of Islamic Conference 1974 (OIC), dilihat dari isu yang diatur maka dapat dikatakan bahwa Piagam ASEAN relatif lebih komprehensif. Sebagai contoh, dari ketiga organisasi kawasan lainnya tersebut di atas yaitu OAU, OAS dan OIC, hanya Piagam ASEAN yang mengatur secara rinci ketentuan mengenai mekanisme penyelesaian sengketa, walaupun dalam hal jumlah negara anggota adalah yang paling

\footnotetext{
${ }^{19}$ Terms of Reference atau TOR HLP disepakati pada Pertemuan ASEAN Foreign Ministers' Retreat di Singapura, 20 Februari 2008; Di dalam TOR, HLP diminta untuk antara lain “,,'(4). The High Level Panel shall draft the Terms of Reference of the ASEAN human rights body in conformity with the purposes and principles of the ASEAN Charter relating to the promotion and protection of human rights and fundamental freedoms (5). The High Level Panel shall address the mandate, membership and of the ASEAN human rights body, as well as its relationship with other relevant human rights bodies in ASEAN (6). The High Level Panel shall undertake consultations with the appropriate stakeholders in ASEAN..."

${ }^{20}$ Pasal 5 Piagam ASEAN "(1). Member States shall have equal rights and obligations under this Charter (2). Member States shall take all necessary measures, including the enactment of appropriate domestic legislation, to effectively implement the provisions of this Charter and to comply with all obligations of membership (3). In the case of a serious breach of the Charter or non-compliance, the matter shall be referred to Article 20"
} 
sedikit. ${ }^{21}$ Hal lain yang menarik adalah jumlah dari tujuan dan prinsip yang tercantum di dalam Piagam ASEAN yang juga relatif lebih komprehensif. ${ }^{22}$

\section{Piagam Asean Sebagai Law Making Treaty di Asean}

Keberlakuan Piagam ASEAN berimplikasi pada perkembangan hukum internasional baik di kawasan ASEAN maupun di Indonesia. Di kawasan ASEAN, wujud sebagai sebuah perjanjian menjadikan Piagam ASEAN salah satu sumber hukum internasional bagi seluruh negara anggota ASEAN. ${ }^{23}$ Melihat dari isi yang diperjanjikan, Piagam ASEAN bukan saja sebuah perjanjian internasional biasa, melainkan perjanjian internasional yang mempunyai karakter khusus untuk dijadikan dasar bagi perjanjian internasional atau instrumen lainnya. Piagam ASEAN mempunyai karakter law-making bagi perjanjian atau instrumen ASEAN lainnya, baik turunan subordinasi ataupun sejajar koordinasi.

Piagam ASEAN dikatakan mempunyai karakter law-making (traitslois) di kawasan ASEAN karena antara lain (i) memberikan aturan-aturan umum (ii) dibentuk secara multilateral, dalam konteks ASEAN adalah regional dan (iii) tidak membatalkan kewajiban perjanjian lainnya. ${ }^{24}$ Dalam kategori (i), sebagai contoh Piagam ASEAN memberikan prinsip-prinsip dasar bagi negara-negara anggota ASEAN dalam berinteraksi di ASEAN. Dalam kategori (ii), Piagam ASEAN adalah sebuah hasil negosiasi regional yang menyelaraskan seluruh kepentingan negara-negara anggota ASEAN dalam sebuah kesepakatan yang mengikat secara hukum. Sedangkan dalam kategori (iii), Piagam ASEAN tidak membatalkan perjanjian lainnya, bahkan mengakui dan menyatakan bahwa kesepakatan terdahulu sebelum pembentukan Piagam ASEAN tetap berlaku selama tidak bertentangan.

\footnotetext{
${ }^{21}$ Data keanggotaan per 2008: OAU 32 negara anggota, OAS 146 negara anggota dan OIC lebih dari 14 negara anggota

${ }^{22}$ Piagam ASEAN 15 Tujuan dan 14 Prinsip, Piagam OAU 5 Tujuan dan 7 Prinsip, Piagam OAS 8 Tujuan dan 14 Prinsip dan Piagam OIC 7 Tujuan dan Prinsip

${ }^{23}$ Lihat Pasal 38 Statuta Mahkamah Internasional

${ }^{24}$ Lihat John O'Brien, International Law, Routledge Cavendish, 2001, hlm. 82; Lihat juga Jan Klabbers, The Concept of Treaty in International Law, Martinus Nijhoff Publishers, 1996, hlm. 13 - 20; Lihat juga Rudiger Wolfrum dan Volker Roben, Developments of International Law in Treaty Making, Springer, 2005 hlm. 39
} 


\section{A. Instrumen Asean Pra Piagam Asean}

Menurut Sekretariat ASEAN, saat ini lebih dari 300 jenis instrumen yang telah disepakati oleh negara ASEAN sejak tahun $1967^{25}$ Jenis instrumen ini terbagi dari berbagai macam bentuk, mulai dari deklarasi, pernyataan bersama sampai nota kesepahaman dan perjanjian internasional di berbagai bidang dengan ekonomi sebagai bidang terbanyak pengaturannya.

Terhadap keberadaan instrumen-instrumen seperti tersebut di atas, Piagam ASEAN dengan karakter law-making, mengakui dan menyatakan bahwa status instrumen yang dibuat sebelum keberlakukan Piagam ASEAN tetap berlaku selama tidak bertentangan. ${ }^{26}$ Sekilas, aplikasi prinsip tetap berlaku selama tidak bertentangan untuk instrumen-instrumen pra Piagam ASEAN tidak mempunyai implikasi terhadap ASEAN, namun demikian jika ditilik lebih jauh hal ini membawa potensi masalah di masa depan. Sebagai contoh, dari 300 lebih jumlah instrumen yang ada, belum dapat ditentukan kualifikasi instrumen hukum yang dapat menimbulkan hak dan kewajiban.

Isu kualifikasi tentang instrumen hukum berkaitan erat dengan mekanisme penyelesaian sengketa karena dari jenis instrumen ini pada umumnya sebuah sengketa didasarkan. Jika sebuah instrumen tidak secara jelas mengatur tentang hak dan kewajiban hukum dan kemudian salah satu pihak dari instrumen tersebut tidak melaksanakan kewajibannya, apakah hal tersebut dapat dijadikan dasar untuk memulai sebuah sengketa? Contoh lain, dari 300 lebih jumlah instrumen dimaksud, apakah ada bentuk hirarki atau semua instrumen mempunyai status yang sama? Hal-hal seperti ini yang harus segera diperhatikan oleh ASEAN untuk menghindari potensi sengketa di masa mendatang.

${ }^{25}$ Laporan dari ASEAN Sekretariat yang diserahkan kepada HLEG dan telah dijadikan sebagai dokumen resmi dari Summary Record of HLEG's Meetings

${ }^{26}$ Pasal 52 Piagam ASEAN "(1). All treaties, conventions, agreements, concords, declarations, protocols and other ASEAN instruments which have been in effect before the entry into force of this Charter shall continue to be valid (2). In case of inconsistency between the rights and obligations of ASEAN Member States under such instruments and this Charter, the Charter shall prevail"; Lihat juga sebagai perbandingan Pasal 103 Piagam Perserikatan Bangsa-Bangsa 1945 


\section{B. Instumen Asean Pasca Piagam Asean}

Instrumen ASEAN pasca Piagam ASEAN sudah seharusnya mengikuti sebuah sistem yang seiring dengan Piagam ASEAN. Kualifikasi yang mencakup tapi tidak terbatas pada hirarki dan status dari masingmasing instrumen baik hukum maupun politis seyogyanya sudah disepakati.

Selain sistem kualifikasi yang baik, ada beberapa turunan dari Piagam ASEAN yang menjadi pekerjaan rumah bagi ASEAN, yaitu antara lain, perjanjian tentang hak kekebalan dan keistimewaan seperti yang dimandatkan oleh Bab VI Piagam, kesepakatan tentang badan HAM ASEAN sesuai dengan Pasal 14 Piagam dan kesepakatan tentang mekanisme penyelesaian sengketa dari Pasal 25 Piagam. Selain itu, peran Sekretariat ASEAN akan menjadi sangat penting sebagai pusat kegiatan ASEAN termasuk pusat instrumen-instrumen ASEAN yang akan dibuat nantinya.

Dengan keberadaan Piagam ASEAN, hukum internasional, khususnya di dalam kawasan ASEAN mengarah kepada sebuah kondisi kepastian hukum yang lebih baik dibandingkan dengan sebelumnya. Akan menarik untuk mengamati implementasi Piagam ASEAN di masa depan baik dalam bentuk perjanjian atau instrumen turunan subordinasi atau sejajar koordinasi. Prospek dan tantangan terbesar bagi hukum internasional dalam konteks ASEAN adalah hal klasik yang telah menjadi momok hukum internasional yaitu kemauan politik atau political will dari setiap negara anggota ASEAN untuk melaksanakan ketentuan dari Piagam ASEAN.

\section{Piagam Asean Sebagai Hukum Nasional Indonesia}

Dengan diratifikasinya Piagam ASEAN oleh Indonesia, maka Piagam ASEAN telah secara resmi menjadi bagian dari hukum nasional Indonesia. Beberapa implikasi hukum Piagam ASEAN bagi Indonesia, utamanya adalah pengakuan ASEAN sebagai sebuah organisasi internasional yang mempunyai kapasitas hukum dalam kaidah hukum nasional Indonesia. Kapasitas hukum dimaksud adalah antara lain (i) membuat kontrak (ii) menjualbelikan properti dan (iii) hak untuk menuntut dan dituntut di muka pengadilan. Seberapa jauh sebuah organisasi internasional dapat dituntut di muka pengadilan Indonesia atau apakah sebuah organisasi internasional dapat memiliki tanah di Indonesia adalah beberapa 
pertanyaan mendasar yang belum dapat dijawab oleh hukum Indonesia saat ini.

Selain itu, implikasi hukum lainnya adalah tentang hak kekebalan dan keistimewaan ASEAN di Indonesia. Secara khusus Indonesia belum memiliki hukum yang mengatur tentang organisasi internasional. Hukum Indonesia yang berkaitan dengan hak kekebalan dan keistimewaan sebuah organisasi internasional masih tersebar dalam peraturan yang lebih umum, seperti Undang-Undang No.24 Tahun 2000 tentang Perjanjian Internasional, Undang-Undang No.37 Tahun 1999 tentang Hubungan Internasional dan Perjanjian-Perjanjian Tuan Rumah atau Host Country Agreements terkait yang pada titik tertentu berbenturan dengan peraturan lain seperti contohnya antara lain peraturan pajak dan imigrasi.

Urgensi hukum yang mengatur tentang organisasi internasional menjadi sangat relevan mengingat dalam konteks ASEAN, Indonesia telah dipercaya untuk menjadi tuan rumah untuk ASEAN. Hal mana seperti layaknya tuan rumah untuk Perserikatan Bangsa-Bangsa bagi Amerika Serikat, Swiss, dan Austria. Intensitas pertemuan-pertemuan ASEAN di Jakarta akan menjadi sangat tinggi ${ }^{27}$ sehingga bukanlah suatu hal yang mengada-ada jika benturan terhadap aturan hukum Indonesia akan terjadi, terlebih jika hukum Indonesia belum secara jelas dan khusus mengatur tentang organisasi internasional. Lebih jauh, setiap negara anggota ASEAN akan menempatkan satu misi tambahan yang mencakup pejabat setingkat Duta Besar seperti layaknya perwakilan tetap negara anggota Perserikatan Bangsa-Bangsa di New York, Amerika Serikat dan ini belum termasuk negara-negara non-ASEAN yang memiliki hubungan tertentu dengan ASEAN seperti halnya mitra dialog ASEAN. Sebagai contoh, Australia telah mengirimkan Duta Besar khusus ASEAN ke Jakarta.

Bagi Indonesia, implikasi tuan rumah adalah prospek dan tantangan sendiri baik bagi hukum Indonesia maupun hubungan antara hukum Indonesia dengan hukum internasional mengingat karakter perjanjian internasional Piagam ASEAN. Bagi Indonesia, prospek dan tantangan hukum internasional pasca Piagam ASEAN dapat ditilik dari dua segi, yaitu segi internal dan segi eksternal. Untuk segi internal, hukum Indonesia akan

${ }^{27}$ Menurut jadwal Sekretariat Nasional ASEAN Indonesia, volume perundingan ASEAN yang akan diadakan di Jakarta untuk tahun 2009 adalah lebih dari 300 pertemuan. 
dipengaruhi oleh hukum internasional, khususnya hukum organisasi internasional. Hukum Indonesia harus dapat menjembatani antara kepentingan hukum internasional dan kepentingan hukum nasionalnya.

Untuk segi eksternal, praktik Indonesia sebagai tuan rumah untuk ASEAN akan dilihat oleh mayarakat internasional, khususnya masyarakat ASEAN dan bukan suatu yang mustahil akan menjadi padanan internasional yang nantinya akan bermuara pada sebuah kebiasaan internasional yang diakui dan dicontoh oleh masyarakat internasional. Jika hal ini terjadi maka, dapat dikatakan Indonesia ikut serta secara langsung dalam membentuk hukum internasional melalui kebiasaan hukum internasional atau customary international law.

\section{Penutup}

Dengan berlakunya Piagam ASEAN, berlaku pula babak baru baik bagi ASEAN sebagai sebuah organisasi kawasan maupun Indonesia sebagai anggota ASEAN. ASEAN telah memiliki sebuah kerangka hukum dan institusional yang mengikat untuk mencapai tujuan bersama yang telah disepakati. Dengan Piagam ASEAN, ASEAN telah berubah dari organisasi yang longgar menjadi organisasi yang berdasarkan aturan atau rules-based organisation. Hal ini secara otomotis memberikan dampak kepada perkembangan hukum internasional, khususnya di kawasan ASEAN mengacu kepada status Piagam ASEAN sebagai perjanjian internasional yang menjadi salah satu sumber hukum internasional.

Dalam konteks ASEAN, keberadaan Piagam ASEAN diharapkan dapat menjadi sebuah percepatan dalam mewujudkan visi masyarakat ASEAN 2020. Prospek dan tantangan hukum internasional bagi ASEAN pasca Piagam ASEAN dilihat dari sisi perjanjian internasional adalah implementasi Piagam ASEAN yang memerlukan tindak lanjut bersama dengan kemauan politik yang kuat yang mensyaratkan antara lain adanya sebuah sistem yang baik dalam pelaksanaannya.

Bagi Indonesia sendiri, prospek dan tantangan hukum internasional pasca Piagam ASEAN dari sisi perjanjian internasional terbagi menjadi dua segi, yaitu segi internal dan eksternal. Untuk segi internal Indonesia perlu untuk melakukan pembenahan hukum yang mengatur tentang organisasi internasional. Indonesia dalam hal ini dipengaruhi oleh hukum internasional. Sedangkan untuk segi eksternal, posisi Indonesia sebagai tuan rumah dari ASEAN dapat mempengaruhi perkembangan hukum 
internasional, khususnya berkenaan tentang hukum organisasi internasional.

\section{Daftar Pustaka}

Anthony Aust, Modern Treaty Law and Practice, Cambridge University Press, 2000

Jan Klabbers, The Concept of Treaty in International Law, Martinus Nijhoff Publishers, 1996

John O'Brien, International Law, Routledge Cavendish, 2001

Rudiger Wolfrum,dan Roben, Volker, Developments of International Law in Treaty Making, Springer, 2005

Konvensi Wina tentang Hukum Perjanjian, 1969

Piagam Association of Southeast Asian Nations, 2007

Piagam Organisation of African Union, 1963

Piagam Organisation of American States, 1948

Piagam Organisation of Islamic Conference, 1974

Piagam Perserikatan Bangsa-Bangsa, 1945

Statuta Mahkamah Internasional 1945

Undang-Undang No. 38 Tahun 2008 tentang Pengesahan Charter of the Association of Southeast Asian Nations (Piagam Perhimpunan BangsaBangsa Asia Tenggara)

Undang-Undang No. 24 Tahun 2000 tentang Perjanjian Internasional

Undang-Undang No. 37 Tahun 1999 tentang Hubungan Internasional

Deklarasi Bangkok, 1967

Deklarasi CEBU tentang Cetak Biru Piagam ASEAN

Deklarasi Kuala Lumpur, 2005

Summary Records of High Level Legal Experts Group Meetings, 2008

Terms of Reference of Eminent Persons Group on the ASEAN Charter, 2005

Terms of Reference of High Level Legal Expert Groups on the Follow-up to the ASEAN Charter, 2008

Terms of Reference of High Level Panel on an ASEAN human rights body, 2008

Terms of Reference of High Level Task Force on the Drafting of the ASEAN Charter, 2005 